Filozofska fakulteta Univerze v Ljubljani

ignac.fock@gmail.com

\title{
SPREGLEDANI PODNASLOV: GOSPA BOVARY IN SLOVAR SPLOŠNO PRIZNANIH RESNIC
}

\section{UVOD}

Dogodka, katerih sopostavitev sicer učinkuje groteskno, sta dve leti tega bržkone zbudila vsaj nekaj zanimanja pri (slovenskem) »flaubertoslovju«. Nobelovo nagrado za književnost je prejel perujski pisatelj Mario Vargas Llosa, v čigar obsežni in tudi v slovenskih prevodih vsaj kvantitativno zgledno zastopani opus se prišteva nemara obrobno, večini neznano, za stroko pa nadvse dragoceno delo: literarni esej z naslovom La orgía perpetua (Brezkončna orgija), izčrpna študija o romanu Gospa Bovary. Že nekoliko poprej pa je Državna maturitetna komisija za slovenščino predpisala roman Gustava Flauberta Gospa Bovary (skupaj z Lainščkovim Ločil bom peno od valov) za maturitetni esej 2011. Naslov tematskega sklopa: »Razpotja ljubezni «. ${ }^{1}$

Maturitetno branje Flaubertovega romana je že samo z naslovom začrtano kot branje ljubezenske zgodbe, Mario Vargas Llosa pa kljub teoretsko utemeljeni razpravi posebno v prvem delu Brezkončne orgije govori, in to tudi priznava, zlasti o sebi ter popisuje svojo »ljubezensko zgodbo« (Vargas Llosa 2006, 742) z Emmo Bovary. V ospredje torej sili lik ženske, za katero je Gustave Flaubert dejal »to sem jaz! « - izjava, ki jo literarna zgodovina še danes na véliko zlorablja - porazgubi pa se druga perspektiva romana: tista, ki ga, kot bo razloženo, pronicljivo sklene v zadnji povedi, ${ }^{2}$ ga vpenja $v$ čas in prostor, predvsem pa v družbeni in družabni kontekst; ne nazadnje tista, s katero je, med drugim, utemeljena oprostilna sodba o domnevni nemoralnosti romana, ki je pisatelja pripeljala pred sodišče: »l'ouvrage dont Flaubert est l'auteur est une ouvre qui paraît avoir été longuement et sérieusement travaillée, au point de vue littéraire et de l'étude des caractères « (»Le procès de Madame Bovary«, v: Flaubert 1964/II: 750). Gre za perspektivo študije značajev, za reprezentativen vzorec ljudi v najbolj kanonskem pomenu izraza literarni liki, s katerimi Flaubert poseli podeželska mesta in pri tem postavi »aksiom«, da je »sovraštvo do buržoazije prvi korak h kreposti«. Gospa Bovary namreč ni zaman podnaslovljena kot Značaji s podeželja.

1 Moj namen ni poglobljeno razpravljati o vsebini dotičnega maturitetnega kataloga, ampak slučajno sovpadanje teme tega članka s primerom Maturitetnega eseja 2011 izkoriščam le za ponazoritev določenih bralnih (ali celo bralskih) predsodkov, za katere pa dejansko ravno v primeru didaktike književnosti (gl. četrti razdelek) obstaja nevarnost, da prerastejo $\mathrm{v}$ floskule ali, natančneje povedano, didaktične splošno priznane resnice. O slednjih bo govora v nadaljevanju.

2 »Pred nedavnim je prejel častni križec.«(Flaubert 2005: 448) 
Namen pričujočega prispevka je opozoriti, da Gospa Bovary ni (samo) roman o Emmi Bovary in da (ljubezensko) zgodbo junakinje osmislijo, če ne celo upravičijo, šele oziroma v prvi vrsti poteze omenjenih »značajev s podeželja«. Dokazati nameravam, da za ta roman obstaja sila konkretna sociološko-zgodovinsko-literarna in s Flaubertovega stališča kar teoretska »scenografija«, ki jo predstavlja Slovar splošno priznanih resnic, pisateljevo fragmentarno, na prvi pogled obrobno delo, za katero pa se izkaže, da funkcionira kot presek ali celo kot sinteza njegovega opusa.

\section{SLOVAR SPLOŠNO PRIZNANIH RESNIC}

Z idejo o "projektu moralnega maščevanja«, kot ga je označil v pismu Louise Colet, se je Flaubert poigraval že pred letom 1850, ko je o svojih nakanah poročal prijatelju Louisu Bouilhetu. Zadal si je namreč nalogo katalogizirati človeško neumnost, pozitivistično urejeno in enciklopedično zabeležiti floskule, puhlice, klišeje, normirane zmote in naučene banalnosti, s katerimi operira povzpetniško malomeščanstvo, ter taistim ljudem $\mathrm{v}$ uporabo predložiti to zrcalo njihove lastne neumnosti in mediokritete. Formalno je torej Slovar resnično - slovar, katerega po abecedi razporejena gesla predstavljajo splošno priznane resnice.

To globoko satirično delo je Flaubert spočetka nameraval priključiti romanu Bouvard in Pécuchet o dveh pariških uradnikih, ki se preselita na podeželje in se obsesivno lotevata (kvazi)znanstvenih študij s prav vseh področij. Obe deli sta, nedokončani, izšli postumno; Slovar prvič kot dodatek k ponatisu »krovnega« romana, leta 1910, v samostojni obliki pa tri leta zatem.

Idée reçue ima v Franciji dolgo tradicijo. Poimenovanje prvič zasledimo v Voltairovih Filozofskih pismib: »Il est certain que la Sainte Écriture, en matière de physique, s'est toujours proportionnée aux idées reçues; [...] (Voltaire 1988: 163), čeprav velja, kot navaja Anne Herschberg Pierrot (1994: 102), zasnovo zanje iskati v 17. stoletju pri Pascalu, kjer je »idée« nadomeščena $z$ »opinon«, v obeh primerih pa gre za povezavo s poljudnostjo in predsodkom: »en association avec les, idées vulgaires" et les ,préjugés vulgaires" "(Ibid. 103). Voltaire idée reçue sčasoma opredeli kot antipod vrojenih idej (»idées innées«), francoski enciklopedist in filozof baron d'Holbach jih primerja $z$ dogmami ter se jim zato ostro zoperstavi, medtem ko jih francoski moralist Nicolas Chamfort, čigar maksimo št. $\mathrm{CXXX}^{3}$ je Flaubert uporabil za epitaf Slovarja, koncem 18. stoletja poveže z družbenim redom: gre za formulacijo tistega, kar velja in se spodobi.

Le Flaubertovo idée reçue pa lahko slovenimo ${ }^{4}$ kot splošno priznano resnico, kajti šele Slovar (Le dictionnaire des idées reçues) ji prinaša semantično inovacijo. Izraz je tod nerazdružljivo povezan $\mathrm{z}$ ironijo in s satiro, pa tudi $\mathrm{z}$ lingvističnimi mehanizmi, kot sta polisemija in homonimija, na katerih $v$ določenih primerih slo-

3 »Trdimo lahko, da je vsako javno prepričanje, vsaka ustaljena norma neumnost, saj ugaja najširšemu krogu ljudi.« (Flaubert 2010: 43)

4 Prevod te besedne zveze mora biti ustrezno osmišljen tako v družbeno-zgodovinskem kot v literarnem kontekstu izvirnika, pri tem pa mora najti prepričljivo mesti v okviru Flaubertovega opusa ter, naposled, suvereno in nedvoumno zdržati tudi v aktualni rabi (cf. Flaubert 2010: 21-26). 
ni njegova komičnost. Poleg tega ustreza kvaziznanstvenemu diskurzu pisarjev Bouvarda in Pécucheta ter, ne nazadnje, dobi ciljno publiko: (malo)meščanstvo, ki se mora naučiti, kaj je »treba reči v družbi, da bi vas imeli za uglajene in prijazne «" Flaubert je splošno priznane resnice konkretiziral, ne da bi jih prikrajšal za površinsko veljavnost, zlasti pa jih je kot neke vrste družbeno ali družabno podstat $\mathrm{v}$ večji ali manjši meri ter nalašč ali podzavestno vtkal v celoten opus. ${ }^{6}$

Intertekstualnost, na kateri bodo temeljili moji argumenti, ni niti najpreglednejši niti samoumeven segment Slovarja, v kolikor izhajamo iz pisateljevega izpričanega namena tega bizarnega projekta, zato je v pretežni meri vendarle zgolj faktografska konstatacija, kajti Slovar kot presek oziroma sinteza ne predpostavlja prej obratno - tematske ali idejne enoznačnosti Flaubertovega literarnega opusa. V izogib posploševanju se bom tako ob predstavljanju vzporednic z Gospo Bovary zatekel k poimenovanju »družbena scenografija «, s katerim lahko natančneje označim enega od vidikov Slovarja - tistega, ki potom splošno priznane resnice konkretizira družbeni kontekst, v katerega je bil ali pa šele bo postavljen roman.

\section{SPLOŠNO PRIZNANE RESNICE V GOSPE BOVARY}

\subsection{Družbena scenografija}

Opažanja domala shematičnih vzporednic med obravnavanima deloma zasledimo pri kar nekaj avtorjih, čeprav redkokateri izhaja iz neposrednih vplivov pisateljevega dolgoletnega kopičenja slovarskih gesel na genezo Gospe Bovary - ali pa obratno, če upoštevamo, da se je Flaubert Slovarju organizirano posvetil v času raziskovalnega dela in priprav za pisanje svojega poslednjega romana, Bouvard in Pécuchet.

Thierry Laget v izdaji Madame Bovary pri Gallimardu (cf. Flaubert 2001) opozarja na pasuse, $\mathrm{v}$ katerih je moč prepoznati gesla iz Slovarja splošno priznanib resnic. Alain Thibaudet meni, da obstaja celo povezava med splošno priznanimi resnicami in kurzivo v Gospe Bovary: besede v kurzivi naj bi bile »comme des morceaux du Dictionnaire des idées reçues que Flaubert place tout bruts dans le style de ce roman« (Thibaudet 1973: 275). ${ }^{7}$

V španski jezik je Slovar splošno priznanih resnic preveden kot Diccionario de lugares comunes, in zanimivo je, da se ravno to, klasično, a v našem primeru netočno poimenovanje $e^{8}$ loci communes oziroma topoi - pojavi v Brezkončni orgiji. Mario Vargas Llosa namreč aspekt Gospe Bovary, ki ga tule izpostavljam skozi prizmo

\footnotetext{
$5 \quad$ V pismu Louise Colet 16. decembra 1852.

6 Cf., za podrobno analizo koncepta splošno priznane resnice (idée reçue), Anne Herschberg Pierrot (1994) (gl. bibl.); o Slovarju splošno priznanib resnic več v spremni besedi iste avtorice k zadnji francoski izdaji (Herschberg Pierrot 1997) in v spremni besedi avtorja tega članka k slovenskemu prevodu (gl. bibl.).

7 Temu prišteje še eno pomembno vprašanje, in sicer polpremi oziroma prosti odvisni govor (discours indirect libre), ki predstavlja posebno poglavje v študijah o Gospe Bovary. Claudine Gothot-Mersch se tovrstnemu sovpadanju zoperstavi: »c'est plutôt le style direct qui est inséré ,tout brut' « (1983: 212), iz česar gre sklepati, da zavrača tudi tipografsko manifestacijo splošno priznanih resnic, četudi o le-teh $\mathrm{v}$ povezavi $\mathrm{z}$ romanom konkretno ne razpravlja.

8 Izraz lieu commun (»Idée, formule générale souvent répétée et appliquée à un grand nombre de situations.«(TLF)) navsezadnje pozna tudi francoščina, toda težko bi rekli, da gre za sinonim idées reçues (»Idée(s) toute(s) faite(s); préjugé(s).«(TLF)), ki jih Trésor de la langue française ponazarja prav s Flaubertovimi.
} 
Slovarja, parafrazira po eni strani s tipizacijo literarnih oseb, po drugi pa s klišeji kot nosilci določene retorične vrednosti, kar splošno priznane resnice dejansko so: »Me gusta mucho que Madame Bovary pueda leerse también como una colección de tópicos, que haya en ella tipos-clisés« (Vargas Llosa 2006: 719).

Predvsem s stališča Slovarja pa intertekstualnost kot družbenoscenografsko podstat Gospe Bovary obravnava Anne Herschberg Pierrot:

Le projet semble bien accompagner la génèse de Madame Bovary. L'interaction est nette entre le roman et les articles du Dictionnaire. [...] Flaubert met en place dans son cuuve romanesque une stéréotypie romantique et une stéréotypie du bourgeois, qui refont surface dans le Dictionnaire des années 1870. (Herschberg Pierrot 1997: 8)

Namigne na dva ključna proporca splošno priznane resnice: malomeščanskost in romantični stereotipi; ${ }^{9}$ po njenih besedah »Le Dictionnaire appelle [...] une mémoire de l'œuvre, où Madame Bovary occupe une place privilégiée« (Ibid. 33).

$\mathrm{Na}$ obračun z romantičnim stereotipom pa moramo gledati tudi skozi nikdar razrešeno dilemo, ali je Flaubert romantik ali realist, in upoštevati izreden pomen njegovega (tako pronicljivega!) razmisleka o lastnih delih, ki jih javnost $\mathrm{v}$ času nastajanja Bouvarda in Pécucheta ni poznala: govorim o prvi verziji Vzgoje srca (iz leta 1845) ter o mladostnih povestih, ki so skupaj s širokim naborom fragmentarnih tekstov izšle po njegovi smrti. Gustave Flaubert ob ironiziranju ali pač premlevanju klišejev romantike (ne tu ne drugod, si upam trditi) ne zataji dejstva, da je njen dedič, distancira se edinole od predsodkov, s katerimi se je, deloma po lastni krivdi, ta estetika soočala $\mathrm{v}$ dobi, ki je njega na piedestal povzdignila kot realističnega pisatelja in opevala njegovo objektivnost.

Po drugi strani pa Flaubertov koncept idée reçue odlikuje satira povzpetniške mediokritete in banalnosti meščanov; v Gospe Bovary je prototip povzpetnika kakopak Homais - zastopa namreč ciljno publiko Slovarja, čemur pritrjuje Anne Herschberg Pierrot (Ibid. 34). Ob tovrstnih ugotovitvah roman naposled lahko beremo ne toliko $z$ druge perspektive, pač pa upoštevajoč širše okoliščine - slednje je celo bolj po meri realističnega romana, četudi se tej oznaki že vseskozi izogibam. Paradoksalno je, da táko, »popolno « percepcijo konverzacijske mimetičnosti zagotavlja določena pripovedna rahločutnost, ki bi jo realizem kot mimetičen v principu zavrnil.

Ker je Slovar za meščana neke vrste »konverzacijski priročnik « - urejeno podaja tisto, kar je »treba reči v družbi, da bi vas imeli za uglajene in prijazne« - bi bil Homais najbrž njegov zgleden uporabnik:

Apotekar bi se v preǰ̌njih časih še kako izogibal takšnemu govorjenju; zdaj pa se je nagibal k razposajenemu obnašanju po pariškem vzoru, ki se mu je zdelo kar se le da okusno, in tako kot soseda, gospa Bovary, je tudi sam pisarja radovedno spraševal po navadah $v$ prestolnici ter celo uporabljal žargon, samo da bi se postavil pred ... meščani z besedami brlog, kaos, važič, težak, Breda Street in zbrišem jo namesto: grem. (GB: 356-357) ${ }^{10}$

9 Ilustratorski odgovor scenografiji splošno priznanih resnic bi bile brez dvoma karikature - slednje so doživele razcvet prav v prvi polovici 19 . stoletja.

10 Vsi citati Gospe Bovary so iz prevoda Suzane Koncut (gl. bibliografijo), zato v izogib ponavljanju reference navajam samo kratico (GB) in stran. 
V kolikor se spomnimo slovarskih gesel o rjavolaskah, blondinkah, rdečelaskah, črnkah in belkah (»Vročekrvnejše so od ...«), pa je podobnost ne le v formulaciji, marveč tudi v vsesplošni, sprotni sodbi, ki povodom vztrajne rabe obvelja in jo ta (zmotna) raba celo utemeljuje, več kot očitna:

Vrb tega so [bile Homaisu] všeč samo rjavolaske. »Strinjam se z vami, «je rekel lekarnar. "Živahnejše so. Sklonil se je k prijatelju in mu na ubo naštel znamenja, po katerib je moč spoznati, ali je ženska živahna ali ne. Vmes je dodal še celo nekaj narodoznanstvenih pripomb: Nemke so publoglave, Francozinje labkožive, Italijanke strastne. (GB: 358)

Sklenem lahko, da je bralcu in kritiku Gospe Bovary Slovar dvojno zanimiv. Prvič se dokumentarno ukvarja s sociohistoričnim kontekstom, v tem okviru celo $\mathrm{z}$ antropologijo vsakdanjega življenja, in je vrh vsega kot satira človeške neumnosti, banalnosti in izprijenosti brezčasen. Drugič pa obuja in celo variira romantične klišeje.

\subsection{Splošno priznano v Gospe Bovary - parafraze slovarskih gesel}

$\mathrm{V}$ tem razdelku svoje trditve dokazujem in konkretiziram z (le) nekaterimi primeri sovpadanja Gospe Bovary in Slovarja splošno priznanih resnic, najsi gre za skladnost zgolj po vsebini (torej za bolj ali manj točno parafrazo) ali pa tudi v formulaciji, navajam pa jih tako, kot si sledijo v romanu.

1) Tedaj se je v njem sprostilo mnogo zatrtih stvari; na pamet se je naučil nekaj kupletov in jih prepeval gostom v dobrodošlico, navdušil se je za Bérangerjeve napeve, se navadil pripravljati punč in končno spoznal ljubezen. (GB: 15)

$$
\text { PUNČ Sodik fantovskemu večeru. [...] (SSPR: 107) } \quad \text { S11 }
$$

2) Morje [je Emmo] privlačilo samo zaradi neviht, zelenje pa le, kadar je raslo sredi razvalin. (GB: 50$)$

\section{RUŠEVINE Vas zasanjajo in dajejo pokrajini poetičnost. (SSPR: 111)}

3) Včasih je pomislila, da so to vendarle najlepši dnevi v njenem življenju, medeni tedni, kot pravijo ljudje. A da človek okusi njihove sladkosti, mora na pot proti deželam zvenečih imen, $\mathrm{v}$ katerih so dnevi po poroki polni najbolj nasladnih lenobnosti! (GB: 55)

ITALIJA $\quad$ Po poroki jo je treba videti. - Italiam, Italiam. « Tam pride do stevilnih razočaranj, ni namreč tako lepa, kot pravijo. (SSPR: 75)

4) Kadar je ob nedeljah kdo od sosedov prišel na večerjo, je [Emma] vedno znala pripraviti kako imenitno jed, mojstrsko je na trtine liste razpostavila piramide

11 Tudi pri citiranju prevoda Slovarja splošno priznanib resnic (gl. bibliografijo) navajam le kratico (SSPR) in stran. Zaradi jasnosti ne upoštevam tipografske doslednosti prevoda, in sicer izpuščam s Flaubertovim rokopisom usklajeno prečrtavanje gesel, ki ga v prevodu ohranjam (cf. Flaubert 2010: 30). 
debelih ringlojev, postregla je z marmelado v kupčkih, zvrnjenih na krožnike, in pravila celo, da bo nabavila posodice za izplakovanje ust pred posladkom. Vse to se je precej poznalo pri Charlesovemu ${ }^{12}$ ugledu. (GB: 57)

IZPLAKOVALNIK Znamenje bogastva pri hiši. (SSPR: 75)

5) Na sredini se je naravnost vzpenjalo stopnišče, na levi pa je galerija, obrnjena na vrt, vodila do dvorane $\mathrm{z}$ biljardom, iz katere so se že $\mathrm{z}$ vrat slišali trki slonokoščenih krogel. [...] (GB: 63-64)

»Recite, kar hočete, njegov biljard je prikupnejši od vašega [...].«(GB: 97)

BILJARD Gosposka igra, na deželi nepogresljiva. (SSPR: 49)

6) [Binet je bil] mojster pri kartah, dober lovec in vešč lepopisja, povrh tega pa je imel doma stružnico, na kateri je sebi v zabavo rezljal obročke za prtičke, ki jih je $z$ ljubosumnostjo umetnika in samoljubjem malomeščana grmadil po hiši. (GB: 98)

STRUŽNICA $\quad V$ deževnih dneh jo je na deželi nepogresljivo imeti na podstrě̌ju. (SSPR: 118)

7) »Oh, morje obožujem!« je rekel Léon. »In kaj se vam ne dozdeva,« je odvrnila gospa Bovary, »da duh svobodneje pluje po tej brezmejni širjavi, da se že ob pogledu nanjo duša vzdigne in se napolni z mislimi na neskončnost in na popolnost?«(GB: 106)

MORJE Nima dna. Podoba neskončnosti. Napelje nas $k$ vélikim mislim. (SSPR: 92)

8) (Emma Homaisu) »Katero glasbo pa imate najraje?« - »Oh, nemško, ker se človek ob njej lahko zasanja.« (GB: 107)

NEMCI Ljudstvo sanjačev (zastarelo). (SSPR: 94)

9) Apotekar se je izkazal za soseda, kakršnega si človek lahko samo želi. (GB: 113)

SOSEDJE Poskušajte jih pripraviti do tega, da vam delajo usluge, ne da bi vas to kaj stalo. (SSPR: 116)

10) Tedaj sta spregovorila o omejenosti podeželanov, o življenjskih upih, ki se v njej dušijo, in iluzijah, ki se razpršé. (GB: 198)

ILUZIJE Hlinite, da jib imate veliko. Pritožujte se, da so jih ljudje čisto izgubili. (SSPR: 74) 
11) Okoli šeste ure so se na gostiji ${ }^{13}$, pripravljeni na pašniku gospoda Liégarda, zbrali vsi pomembnejši udeleženci slovesnosti. Ves čas je vladalo najprisrčnejše vzdušje. (GB: 198)

BANKET Tam brez izjeme vlada najiskrenejša prisrčnost. [...] (SSPR: 48)

12) (Obiskovalci tolažijo bolnega Hippolyta.) »Kako je s teboj?« so mu govorili in ga trepljali po rami. »Oh, menda se ne hvališ preveč! «(GB: 230)

BOLNIK Da bi bolniku dvignili moralo, zabavljajte čez njegovo bolezen in zanikajte njegovo trpljenje. (SSPR: 50)

13) »Strinjam se!« je nadaljeval Homais. »Škodljiva književnost se najde, tako kot se najdejo škodljiva zdravila [...].«(GB: 279)

ROMANI Izpridijo množice. V podlistkih so manj nemoralni kot v zvezkih. [...] (SSPR: 111)

14) (Homais Charlesu o igralcih.) »Vsi taki veliki umetniki mečejo denar skozi okno; razuzdano življenje jim je potrebno, da se jim domišljija lahko razvname. Umirajo pa $\mathrm{v}$ hiralnicah, ker v mladih letih niso imeli dovolj pameti, da bi kaj prihranili.«(GB: 281)

IGRALKE Poguba za družinske sinove. Premorejo (fantastično) zastrašujočo opolzkost, vdajajo se (nočnim) orgijam, pogoltnejo milijone, končajo v ubožnici. [...] (SSPR: 73)

UMETNIKI [...] Zaslužijo nore vsote denarja, a jih zmečejo skozi okno. [...] (SSPR: 125)

15) Léon [je Homaisu] prisegel, da se mora vrniti v pisarno. Tedaj se je Homais začel norčevati iz prekladanja papirjev in iz pravd. »Za vraga, pustite no malo te vaše juriste, Cujasa in Barthola! (GB: 360)

CUJAS Neloćljiv od Barthola. - Ni znano, kaj sta pravzaprav napisala, ni pomembno. Recite (tistemu) vsem, ki (študira) studirajo (pravo) zakone: »Morate pa biti zakopani v Cujasa in Bartola." (SSPR: 53)

16) (Na Emminem pogrebu.) Apotekar je povzel besedo: »Vedite, če me ne bi bilo zraven, bi si gotovo storil kaj hudega! - »Tako ljubezniva duša! Če samo pomislim, da je še prejšnjo soboto prišla k meni v prodajalno!« (GB: 434)

POGREB (Recite) V zvezi s pokojnim:»Samo pomislite, da sem še pred tednom dni večerjal $z$ njim! «(SSPR: 102) 
Glede na povedano v prejšnjem razdelku predlagam razlikovanje med splošno priznanimi resnicami, ki imajo v najožjem smislu konverzacijsko vrednost (npr. 12, 15, 16), pa tistimi, ki pričajo o implicitni ironizaciji romantičnih klišejev (npr. 2, 7), ter ne nazadnje onimi - in teh je največ - ki bralca (bolje rečeno: uporabnika) Slovarja učijo socialnih veščin ter nasploh vsega, kar je prefinjeno in gosposko (npr. 1, 3, 4, 5, 6).

Kar zadeva formulacijo, zgolj povzemam zaključke Anne Herschberg Pierrot (1997: 24), ki funkcije slovarskih gesel pojasnjuje na ravni skladnje: gre za razlikovanje med trdilno, vzklično in velelno povedjo. Trdilna naznanja ugotovitev, takšna splošno priznana resnica je normativna in ima brezčasno vrednost (npr. 1, 2, 5); absolutnost implicitno ali eksplicitno lahko krepijo prislovi vedno, vselej, izključno, nikoli, samo, etc. Vzklična poved naznanja čustveno bližino oziroma predlaga naučeno, pričakovano čustvovanje (16) kot družabno vrlino. Pretežni del slovarskih gesel pa je v velelnem naklonu (npr. 9, 10, 12, 16), kar je z ozirom na "priročniško dimenzijo Slovarja logično; v prevodu je to še opazneje iz oblikoslovnih razlogov, saj francoska velelnik in nedoločnik $\mathrm{v}$ slovenščini načeloma terjata velelnik.

$Z$ vidika vsebine po eni in oblike po drugi strani splošno priznane resnice torej grosso modo lahko opišemo ali zamejimo, a je seveda jasno, da tudi ti »vzorci« večkrat sovpadajo in se prekrivajo. Konkretno v Gospe Bovary pa pri proučevanju intertekstualnosti s Slovarjem ni opaziti, da bi kateri koli vidik prednjačil.

\section{SPLOŠNO PRIZNANA RESNICA KOT DIDAKTIČNA ZMOTA}

V luči povedanega želim - še posebej ob dejstvu, da je Gospo Bovary nedolgo tega (v šolskem letu 2010/11) brala cela generacija slovenskih maturantov - na kratko vendarle opozoriti na »bralsko nevarnost «, ki jo ta prispevek deloma izpostavlja že sam po sebi.

Poučevanje književnosti $v$ pretežni meri temelji na bralnem razumevanju oziroma je slednje celo predpogoj za kakršno koli nadaljnjo obravnavo literarnega dela. Učni načrt in, sčasoma, maturitetni katalog pa obravnavi slehernega »kanonskega « besedila v programu pripišeta cilj, ki naj bo z njo dosežen, torej predvidevata in zahtevata jasno opredeljene rezultate, ki jih bo dalo bralno razumevanje. $V$ kombinaciji $z$ razmeroma površnim pozitivizmom se poučevanje književnosti zato nemalokrat zateka k ekstrakciji in esencializaciji, iz česar lahko sledi, da je vzklik »Gospa Bovary, to sem jaz! « v primeru Gustava Flauberta vkorporiran $\mathrm{v}$ snov kot (eventuelno $\mathrm{v}$ testu točkovan) biobibliografski fakt.

»Izobrazba je tisto, kar ostane, ko pozabimo vse, kar smo se naučili v šoli, «je citat Alberta Einsteina, ki ga izobraževalne ustanove pogosto navajajo v ilustracijo svoje dejavnosti. A če je povzemanje lahko metoda, povzetek ne more biti vsebinsko izhodišče. V kolikor pouk književnosti vidimo kot usmerjeno preverjanje bralnega razumevanja $\mathrm{v}$ okviru predvidenih rezultatov, bralno razumevanje ni več razumevanje, pač pa iskanje konkretnega odgovora oziroma formulacije - strnjene (pol)resnice, ki sicer ne ustreza učnemu cilju, vendar je njen pojav oziroma 
težnja k njenemu iskanju s strani učenca/dijaka/študenta lahko le posledica dejstva, da je poučevanje književnosti usmerjeno $\mathrm{k}$ artificielnim ciljem. Žal se namreč izkaže, da so (ocenjevalcu dobrodošle) posplošene sodbe tiste, ki preživijo kot »izobrazba «" ${ }^{14}$, saj je ustaljena in tolikokrat ponovljena formulacija v takšnih primerih (»Gospa Bovary, to sem jaz! «, »roman o prešuštnici«, ipd.) delovala malodane kot mnemotehnično sredstvo.

Ali ne gre pri vsem naštetem ravno za - splošno priznane resnice? »La bêtise consiste à vouloir conclure, « je rekel Gustave Flaubert. Pri poučevanju književnosti naletimo na situacijo, ki s šolsko obravnavo Flauberta preraste v oksimoron: od naučenega o tem avtorju in njegovem najslavnejšem delu bodo (»brž ko pozabijo vse, česar so se naučili v šoli«) ostale splošno priznane resnice, ki jih je konceptualiziral prav on. Če se povrnem k temi tega prispevka: med petdesetimi študenti humanističnih smeri (natančneje: jezika in literature) iz generacije, ki je pol šolskega leta poglobljeno obravnavala roman Gospa Bovary pod parafrazo »Razpotja ljubezni«, ni niti enega, ki bi poznal podnaslov Značaji s podeželja. Razumljivo je, da se maturitetni esej včasih omeji le na en segment literarnega dela, a zato je nemara še toliko bolj paradoksalno, da se (domnevno) poglobljeno poznavanje ozke teme na globalnem nivoju kompenzira s floskulami, ki jih mirno lahko poimenujemo didaktične splošno priznane resnice.

\section{SKLEP}

S sopostavijo del Gospa Bovary in Slovar splošno priznanib resnic sem na konkretnih primerih dokazal pomembne vzporednice med njima. Splošno priznane resnice predstavljajo konkretizacijo te intertekstualnosti, ki se v Gospe Bovary izriše v »družbeno scenografijo«. Kljub vsemu pa je nemogoče reči, ali je bila ta povod za izoblikovanje in formulacijo splošno priznanega, ki se zrcali med drugim $\mathrm{v}$ obravnavanem romanu, ali je slednji nastajal kot posledica tovrstnega procesa; najverjetneje gre za kombinacijo obojega, kakor je tudi Slovar hkrati presek in sinteza Flaubertovega opusa. Nobenega dvoma torej ni, da je Gospo Bovary nujno brati v najširšem okviru izpostavljenega, in ne le kot zgodbo o Emmi Bovary. V oporo tej trditvi za konec navajam še avtorja najbrž najrecentnejše monografije o Flaubertu, Bernarda Fauconnierja, ki zapiše: »On ne comprend rien à Madame Bovary si on ne décèle pas dans ce roman une constante ironie tragi-comique, une charge antiromantique et antibourgeoise dissimulée (à peine) sous les dehors d'une fausse objectivité« (2012: 107).

Bistvo oziroma presežek omenjene družbene scenografije je skrbno skrita satira; podnaslov romana je namig, da bo pisatelj podržal zrcalo malomeščanstvu oziroma neskončni človeški neumnosti, banalnosti, pa tudi nizkotnosti in povzpetništvu, kar bo zares prišlo do izraza šele v Slovarju splošno priznanih resnic. Le-tega posledično vidim (tudi) kot komplementarno čtivo h Gospe Bovary, saj je njegov eksplicitni pomen tisto, kar ostane implicitno v Značajih s podeželja (Mœurs de province): castigare ridendo mores.

14 Nalašč se oklepam izpetega Einsteinovega citata. 


\section{BIBLIOGRAFIJA}

FAUCONNIER, Bernard (2012) Flanbert. Paris: Gallimard (Folio biographies). FLAUBERT, Gustave (1964) CEuvres complètes (2 tomes). Paris: Seuil (L'intégrale). FLAUBERT, Gustave (2001) Madame Bovary (Éd. de Thierry Laget). Paris: Gallimard (Folio).

FLAUBERT, Gustave (2005) Diccionario de lugares comunes. (Trad. de Tomás Onaindia) Madrid: EDAF.

FLAUBERT, Gustave (2005) Gospa Bovary. (Prev. Suzana Koncut.) Ljubljana: Mladinska knjiga.

FLAUBERT, Gustave (2010) Slovar splošno priznanih resnic. (Prev. Ignac Fock.) Ljubljana: Modrijan.

GOTHOT-MERSCH, Claudine (1984) Introduction. G. Flaubert, Bowvard et Pécuchet. Paris: Gallimard, 7-43.

HERSCHBERG PIERROT, Anne (1994) Histoire d'»idées reçues«. Romantisme 24/68, 101-120.

HERSCHBERG PIERROT, Anne (1997) Introduction. G. Flaubert, Le Dictionnaire des idées reçues suivi du Catalogue des idées chic. Paris: LGF, 5-43.

THIBAUDET, Alain (1973) Gustave Flawbert. Paris: Gallimard.

TLF. Trésor de la langue française. 20. oktober. http://atilf.atilf.fr/.

VARGAS LLOSA, Mario (2006) La orgía perpetua. Ensayos literarios I. Barcelona: Galaxia.

VOLTAIRE (1988) Lettres philosophiques. Paris: Garnier.

\section{POVZETEK}

\section{Spregledani podnaslov: Gospa Bovary in Slovar splošno priznanib resnic}

Pričujoči članek je intertekstualna študija Flaubertovega romana Gospa Bovary in njegovega fragmentarnega, postumno izdanega dela Slovar splošno priznanib resnic. Avtor s primeri ponazori tematska sovpadanja in podobnost formulacij ter dokaže prisotnost socioloških, zgodovinskih in literarnih vzorcev, ki so v Slovarju konkretizirani - skorajda teoretsko kot splošno priznane resnice, v romaneskni obliki pa izgrajujejo »družbeno scenografijo«, katere parafraza je tudi podnaslov Gospe Bovary: Značaji s podeželja. Zato opozarja, da Gospa Bovary ni (samo) roman o Emmi Bovary in da zgodbo osmislijo, če ne celo upravičijo, šele poteze omenjenih značajev s podeželja. Pri Flaubertu se konceptualizacija in literarizacija »splošno priznanega odvijata vzporedno, zato o časovni primarnosti ene ali druge ni mogoče govoriti. Vendar v Gospe Bovary ravno kot družbena scenografija dobi podobo zgoščena satira Slovarja, ki ga avtor vidi kot presek in sintezo pisateljevega opusa, hkrati pa kot komplementarno čtivo $\mathrm{k}$ dotičnemu romanu.

Ključne besede: francoska književnost, Gustave Flaubert, Gospa Bovary, Slovar splošno priznanih resnic, intertekstualnost 


\section{ABSTRACT}

\section{Subtitle Overlooked: Madame Bovary and the Dictionary of Accepted Ideas}

The present article is an intertextual study of Flaubert's novel Madame Bovary and his fragmentary, posthumously published work Dictionary of Accepted Ideas. By listing examples of thematic parallelisms as well as those in formulation, the author proves the presence of certain sociological, historical and literary patterns which are, almost theoretically, concretized as accepted ideas in the Dictionary whereas in a novelistic form, they shape a kind of "social scenery", paraphrased also by the subtitle of Madame Bovary: Patterns of Provincial Life. He consequently warns that Madame Bovary is not (merely) a novel about Emma Bovary whose story is, furthermore, given a meaning, if not even justified, only by the mentioned patterns of provincial life. In Flaubert's work, conceptualisation and literarisation of the "universally acknowledged" are simultaneous and no temporal priority can thus be discussed. However, in Madame Bovary it is precisely under the form of social scenery that is reproduced the concise satire of the Dictionary, the latter being therefore perceived by the author as a cross section and a synthesis of the novelist's entire work as well as a complementary reading to this particular novel.

Key words: French literature, Gustave Flaubert, Madame Bovary, Dictionary of Accepted Ideas, intertextuality 